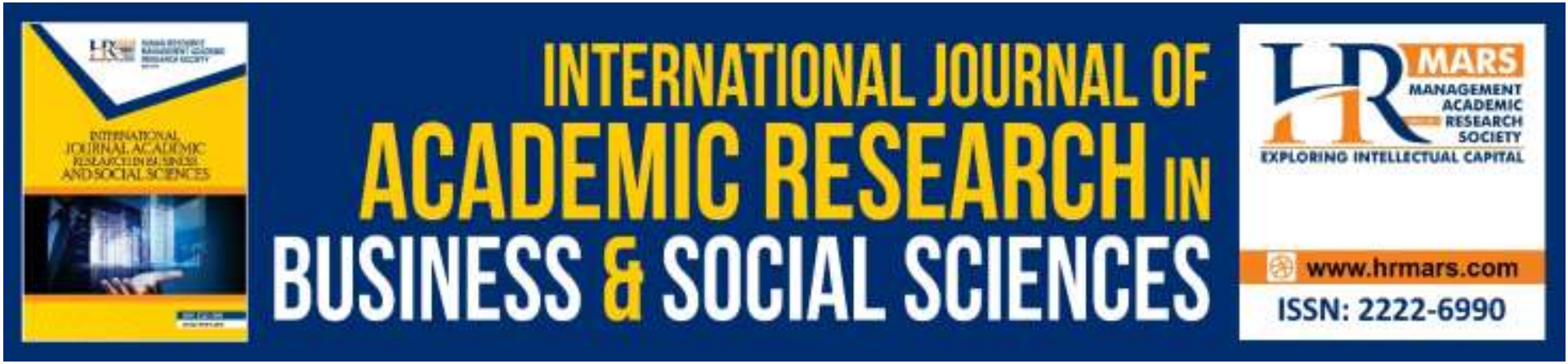

\title{
Strategic Drivers of Sport Commercialization in Kenya: A Survey of Football Subsector
}

\author{
Anthony Onyango Origi, Jared Deya
}

To Link this Article: http://dx.doi.org/10.6007/IJARBSS/v9-i9/6391

DOI: $10.6007 /$ IJARBSS/v9-i9/6391

Received: 08 Oct 2019, Revised: 14 Oct 2019, Accepted: 20 Oct 2019

Published Online: 22 Oct 2019

In-Text Citation: :(Origi \& Deya, 2019)

To Cite this Article: Origi, A. O., \& Deya, J. (2019). Strategic Drivers of Sport Commercialization in Kenya: A Survey of Football Subsector. International Journal of Academic Research in Business and Social Sciences, 9(9), 1017-1035.

\section{Copyright: (C) 2019 The Author(s)}

Published by Human Resource Management Academic Research Society (www.hrmars.com)

This article is published under the Creative Commons Attribution (CC BY 4.0) license. Anyone may reproduce, distribute, translate and create derivative works of this article (for both commercial and non-commercial purposes), subject to full attribution to the original publication and authors. The full terms of this license may be seen

at: http://creativecommons.org/licences/by/4.0/legalcode

Vol. 9, No. 9, 2019, Pg. 1017 - 1035

http://hrmars.com/index.php/pages/detail/IJARBSS

JOURNAL HOMEPAGE

Full Terms \& Conditions of access and use can be found at http://hrmars.com/index.php/pages/detail/publication-ethics 


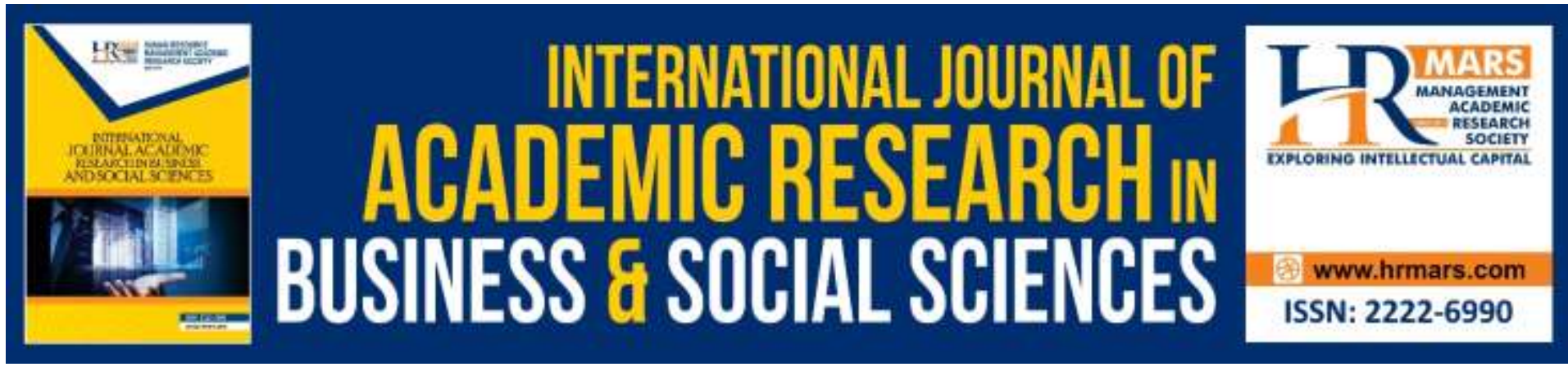

\title{
Strategic Drivers of Sport Commercialization in Kenya: A Survey of Football Subsector
}

\author{
Anthony Onyango Origi \\ Master of Business Administration, Jomo Kenyatta University of Agriculture and Technology, \\ Kenya \\ Email: a.origi@yahoo.com \\ Dr. Jared Deya \\ Jomo Kenyatta University of Agriculture and Technology, Kenya \\ Email: jdeya@jkuat.ac.ke
}

\begin{abstract}
Sports teams and sporting organizations in Kenya have over time not been run commercially as a business and have decried lack of resources to effectively run their affairs towards achievement of success, profitability and impact on the economy. The study examined the influence of strategic drivers of sport commercialization in Kenya within the football subsector. Specifically, the study aimed at establishing the influence of government participation, public relations, capacity development and national culture strategic drivers of sport commercialization in Kenya within the football subsector. The target population was 70 respondents made up of the chairman, marketing manager and treasurer of all football clubs in the Kenya premier league and the Kenya secondary schools sports association, the chief executive officer and treasurer of football Kenya federation and Kenya premier league, marketing and brand manager of Safaricom, Sportpesa, East Africa breweries and Coca-Cola Kenya and director of state department of sport development. Data was collected using structured questionnaires and analyzed using both descriptive and inferential statistics with the aid of SPSS. The results of study established that there was government participation, public relations, capacity development and culture adoption within the football subsector in Kenya. The findings of inferential statistics showed that government participation, public relations, capacity development and culture had a positive and significant effect on sports commercialization within the football subsector in Kenya. The study generally concluded that government participation, public relations, capacity development and national culture were significant strategic drivers for sport commercialization in football subsector in Kenya. The study recommends that management of football organizations in Kenya should deliberately adopt various strategic drivers such as government participation, public relations, capacity development and national culture in ensuring commercialization of football subsector in Kenya.
\end{abstract}

Keywords: Strategic Drivers, Sport, Commercialization, Public, Government, Culture 


\section{Introduction}

\section{Background of the Study}

The history of modern sport details an evolution, from games played primarily for entertainment and leisure to an industry rivaling any other in size and power. The impact of sport in the areas of social policy and social integration contribute greatly to sustainable development. Sports spawn complex, evolving industrial ecosystems with interaction between players, entrepreneurs, the media and public policy makers (Potts \& Thomas, 2018). Commercialization of sport is that aspect of sport that involves the sale, display and advertisement of part or whole aspect of sport so as to produce income. Sport has the ability to generate substantial income from gate receipts, television, internet rights, sponsorships, merchandise and licensing rights (Westerbeek, 2013). Modern sports links to commerce are highly visible. Stadiums and arenas bear the names of businesses; sponsors' logos appear on athletes' clothing, equipment, and event titles. Media companies pay vast sums for the rights to broadcast while advertisers pay a premium to promote screened products, star athletes are transferred for multi-million fees and professional sport franchises sold for sums higher than the gross domestic products of some countries (Westerbeek, 2013). Sporting organizations have established brands and brand loyalty. People are becoming emotionally attracted to teams especially teams with long and proud history and the teams ultimately generate or convert, a new generation of loyal fans. These translate to a powerful mix which in turn attracts communication companies to sport leading to an increase of mass media coverage (Westerbeek, 2013).

Football is the most popular sport in Africa with millions of supporters and hundreds of thousands of players and clubs. From Accra to South Africa, other than its commercialization effects, African football today reflects her history and a rare form of national culture in ethnically diverse nations symbolizing pan-African unity and solidarity (Alegi \& Bolsmann, 2013). The huge popularity of football in South Africa has attracted significant financial investments. In June 2007, the premier soccer league (PSL) signed a three point six billion Rand broadcast deal with super sport international (Alegi, \& Bolsmann, 2013).

Sporting economy in Kenya has been growing over the years though slow in achieving substantial commercialization. According to Agutu, (2018) of The Star in April 2018, online betting firm SportPesa signed partnership agreements worth six hundred and eighty two million Kenya shillings with four local football entities namely Gor Mahia, AFC Leopards, the Kenyan premier league (KPL) and football Kenya federation (FKF). There is growing consciousness of what needs to be done in Kenya so as to achieve economic goals through sports. One of the strategic focal points is the need to deliberately create polices aimed at spurring more sporting investment.

\section{Statement of the Problem}

Sport in particular football in Kenya has over the years been handled as a hobby. Team formations are either community sponsored or supported by the public sector. Sport however, is not only a leisure activity beneficial to health but has also a huge economic impact. In Kenya, sport is yet to be fully commercialized where its effects significantly affect the GDP positively. Although some clubs in Kenya have commenced selling club merchandise as well as broadcast rights, uptake is still insignificant with clubs still unable to meet fully their 
running costs. According to Deloitte's annual review of football finance (2018) after the implementation of what was named the fifty point plan by the Chinese government, commitment to football triggered investment of over two hundred million pounds in playing talent by Chinese super league clubs and by the end of 2017, the nine leading football cub's owners net worth was over seventy five billion sterling pounds.

In 2014, over fourteen billion dollars was spent on sport sponsorships in North America creating an estimated $\$ 14.62$ billion in revenue for the sponsors (Statista, 2015). In the FIFA world cup event held in the republic of South Africa in 2010 the event generated a positive economic impact. The event contributed 509 million dollars to the real GDP, creating 769 million in benefits for households and direct impact on labour of 130,000 jobs created through constructions in stadia, other infrastructure and hospitality (Sport \& Recreation South Africa, 2012)

In the developed world, sport and especially football has evolved and has ceased to be only community sponsored. Private organizations and business moguls have injected multibillion shillings sponsorship resulting to drastic fortune improvement for players, owners and respective economies. Although Kenyan sport particularly football is poised for effective commercialization granted that cooperates are now showing some interest the sector is not yet significant in contribution to the country's economy, clubs are yet achieve huge revenue generation and there are still cases of players not receiving their salaries and allowances. There is therefore a need to establish the factors required to ensure sport commercialization in Kenya. Very few studies have been done on effective commercialization of sport in Kenya: probably non on football. This study, therefore, seek to assess the strategic drivers of sport commercialization in Kenya within the football subsector.

\section{Literature Review \\ Theoretical Background \\ The Marxist Theory of Cultural Hegemony}

In Marxist philosophy, cultural hegemony is the domination of culturally diverse society by the ruling class who manipulate their beliefs, perceptions, values and mores so that their imposed ruling class worldview becomes the accepted cultural norm; the universally valid dominant ideology, which justifies the social, political and economic status quo as natural and inevitable, perpetual and beneficial for everyone, rather than as artificial social constructs that benefit only the ruling class (Bullock \&Trombley, 1999). The hegemony theory is significant to the study as it highlights the influence of the state to society, culture and norms, in this case sport as a cultural reflection of society. Convergence zone is met and realization of mutual interest achieved when sport and state work in harmony; the government provides the necessary legislative base through sports policy, Infrastructure and capacity development and direct funding to various sporting federations within a country. Benefits under such circumstances are mutual. Sport being an economic driver the state derives economic gain through tourism, sports equipment manufacturing or importation, provision of jobs, and the ripple effect

\section{The Excellence Theory}


The Excellence theory is a general theory of public relations that specifies how public relations makes organizations more effective, how it is organized and managed when contributing to organizational effectiveness, the conditions in organizations and the environment that make them more effective and how the monetary value of public relations can be determined (Grunig, 2013). The theory explains that the value of public relations lies in the organization's relationship with its strategic publics. This is relevant to the study since for an organization to develop and achieve goals desired by both the organization and its publics as well as reduce costs of negative publicity and increase revenue by providing products and services needed by stakeholders there is need for good public relations. To maximize the value of public relations, public relations must identify strategic publics and build long term relationships with them through symmetrical communication programs (Grunig, 2008).

\section{Resource-Based Theory}

Resource based theory explains how resources are given the major role of assisting companies in achieving higher organizational performance and competitive advantage. The theory contends that the possession of strategic resources provides an organization with golden opportunity to develop competitive advantage over its rivals and that these competitive advantages in turn can help the organization enjoy strong profits over time. To achieve a sustainable competitive advantage, the resources must be valuable, rare, imperfectly imitable and no-substitutable (Barney, 1991). This means that no other resources can replace them and produce similar value or competitive advantage

\section{Cultural Identity Theory}

According to Lustig (2013) cultural identity refers to a person's sense of belonging to a particular culture or group. This process involves learning about and accepting traditions, heritage, language, religion, ancestry, thinking patterns and social structures of a culture. Normally people internalize the beliefs, values, norms and social practices of their culture and identify themselves with that culture. Cultural identities are central to a person's sense of self because cultural identities are dynamic and multifaceted components of one's self concept and exist within a changing social context and as a result, a person's identity changes as do one's ongoing experiences in life (Lustig, 2013). National culture is a set of norms, behaviors, beliefs, customs, and values shared by the population of a sovereign nation (Pavao, et al, 2019). This theory is linked to sports since sport and culture are widely perceived to generate social impacts. In terms of the social capital, impact of sport is a type of social glue, contributing to bonding capital by increasing social connectedness and a sense of belonging. Positive outcomes in studies include reduced social and ethnic tensions, and more collective action and community involvement through sport (Taylor, et al.2015).

\section{Conceptual Framework}

Conceptual framework is an analytical tool with several variations and context that shows the relationships between the independent and dependent variables. The study used four independent variables namely, government participation, public relations, capacity development and national culture.

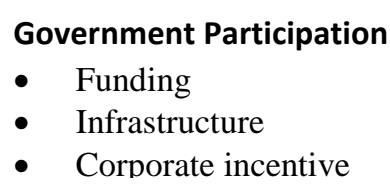


Figure 1: Conceptual Framework

\section{Empirical Literature Review}

Yadav (2016) conducted a research on commercialization of Sports and competition law in India. The study finding shows that existing laws and regulations played a significant impact on commercialization of sports in India. The study revealed a positive impact between government participation and sport commercialization in India. Another study conducted by Slack, (2014) was concerned with the social and commercial impact of sport, the role of government regulations. These finding showed government participation had a positive impact on sport commercialization in Asian Countries. Similarly, Alapartanen \& Kelly (2016) conducted a study on understanding the implications of the sporting industry in the United Kingdom and the United States. The study established that political influence has presence in sport commercialization in these Countries and that sports commercialization required progressive regulation to ensure their socioeconomic impacts are harnessed.

Houlihan (2014) conducted a study on mechanisms of international influence on domestic elite sport policy. In the study of the elite sport development systems in the UK, Australia and Canada, the study concluded that all three countries had, over the previous ten years or so, experienced an increase in government intervention intended to establish and refine elite policy objectives. A study conducted by Serbanica and Constantinescu (2016) focused on using public relations in sports in Romania. The authors concluded that the effective use of public relations in sport can generate conversion, facilitate sport representatives positioning, and maintain continued sport sustenance

Another study in this area was conducted by Hopwood, Skinner \& Kitchin (2012) and focused on sport public relations and communication. The results showed that failure bysport public 
relations professionals to deal with a player's crisis could lead to unsavory or bad press about players and had the potential to call into question a player's reputation and lead to poor public perception of the sport organization and/or sport. Göksel and Serarslan (2015) carried out a study on public relations in three sports clubs, a new media as a strategic corporate communication instrument. It was found out that the sports clubs, among them Galatasaray Sports Club, Fenerbahçe Sports Club and Beşiktaş Gymnastics Club had increasingly paid attention to social media. Corporate communication practitioners modify the structure and operational patterns in the official accounts by taking the reactions of the users into consideration and make necessary additions and corrections when necessary. Also, practitioners believe that the PR they possess in new media have a big impact upon their corporate reputation

Hopwood, (2015) also investigated the effect of public relations practice in English county cricket. A critical finding from this research is that the communications strategies recommended for use in cricket are equally applicable and can undoubtedly offer the same potential benefits to all sports. Balduck, et al. (2015) carried out a study on organizational capacity and organizational ambition in nonprofit and voluntary sports clubs. The study surveyed 172 nonprofit and voluntary sports clubs in UK. The study results showed that organizational capacity was very significant in growth of the nonprofit and voluntary organizations. Doherty, Misener \& Cuskelly (2014) carried out a survey on toward a multidimensional framework of capacity in community sport clubs. Focus groups with presidents of 51 sport clubs across Ontario revealed key strengths and challenges that impact the ability of these organizations to achieve their sport delivery goals.

\section{Research Gap}

The review of existing literature identified three main research gaps that the current study sought to address. First, the study revealed a contextual research gap in existing empirical studies. Studies on sport commercialization reviewed (Yadav, 2016; Slack, 2014; Alapartanen \& Kelly; 2016; Serbanica \& Constantinescu, 2016) were conducted in countries especially from Europe where sport commercialization has grown in lips and bounds. Sports commercialization in such countries is driven by completely different factors compared to sport commercialization in developing countries such as Kenya. Similarly, government participation, public relations, capacity and national culture is at different level compared to countries such as Kenya. The current study therefore addressed this contextual gap by focusing on the strategic drivers of sport commercialization in football subsector in Kenya.

The second research gap identified was methodological research gap where majority of the existing studies (Edwards, 2015; Balduck et al, 2014) did not conduct causal effect relationship between various strategic drivers on sport commercialization. The current study used inferential statistics to test the effect of various strategic drivers on sport commercialization in Kenya hence bridging this methodological gap. Similarly majority of the strategic management literature conducted in Kenya have focused corporate such financial and manufacturing institutions with sports receiving very little attention. Sports in Kenya have major socioeconomic impacts hence ideal for research on how to improve it and make it a more commercial vibrant sector. 
In regards to the study variables, little has been done on the effect of government participation, public relation, capacity development and national culture on sport commercialization in emerging countries. For instance, Yadav (2016) focused on commercialization of Sports and competition law in India, Slack, (2014) studied social and commercial impact of sport, the role of government regulations while Serbanica \& Constantinescu (2016) focused on using public relations in sports in Romania. Edwards, (2015) investigated the role of sport in community capacity building and Doherty, Misener \& Cuskelly (2014) carried out a survey on toward a multidimensional framework of capacity in community sport clubs. This demonstrated there is a research and knowledge gap on the effect of government participation, public relation, capacity development and national culture on sport commercialization which was addressed by the current study.

\section{Research Methodology}

The study adopted a descriptive research design. According to Shields, et al, (2013) descriptive research is used to describe characteristics of a population or phenomenon being studied, it helps provide answers to the questions of who, what, and where, associated with a particular research problem. The target population of the study was made up of the chairman, marketing manager and treasurer of the Kenya secondary schools sports association and of all eighteen football clubs in the Kenya premier league, the chief executive officer, marketing manager and treasurer of football Kenya federation and Kenya premier league, the marketing and brand manager of Safaricom, Sportpesa, East Africa breweries and Coca-Cola Kenya and director of state department of sport development.

Primary data and secondary data were used. Primary data is the data collected a fresh and for the first time making them original in character (Kothari, 2004). The researcher used drop and pick method to collect data. Structured questionnaires were given to respondents and collected after allowing them enough time to complete them. The researcher used contact persons to boost response rate and was available for any clarifications required. Pilot test study was carried out to assess feasibility, appropriateness and practicability of the research design as recommended by Kothary, (2008). Once data was collected, the researcher conducted data cleaning, after which the data was coded and entered in the computer for analysis using the Statistical Package for Social Sciences (SPSS). Data was analyzed using descriptive statistics such as frequency counts, percentages, means and standard deviation. Inferential statistics which is correlation and regression analysis were employed using SPSS. For regression analysis, the study hypothesized the following regression model;

$Y=\beta 0+\beta_{1} X_{1}+\beta_{2} X_{2}+\beta_{3} X_{3}+\beta_{4} X_{4}+\varepsilon$

Where;

$Y$ represented Strategic Drivers of Sport Commercialization in Kenya Football Subsector

$\beta_{0}$ represented a constant and represents the value of $Y$ when $X_{1}, X_{2}, X_{3}$ and $X_{4}=0$

$\beta 1, \beta 2, \beta 3, \beta 4$ represented the regression coefficients which measures the average change in the value of the dependent variable.

$\mathrm{X}_{1}=$ Government Participation

$\mathrm{X}_{2}=$ Public Relations

$\mathrm{X}_{3}=$ Capacity Development

$\mathrm{X}_{4}=$ National Culture

$\varepsilon=$ Error Term 


\section{Findings and Discussions}

\section{Introduction}

The study targeted a total of 70 respondents hence this number of questionnaires was administered during the survey. The results are shown in Table 1.

Table 1 Response Rate

\begin{tabular}{lll}
\hline Response Rate & Frequency & Percent (\%) \\
\hline Questionnaires returned & 64 & 91 \\
Unreturned Questionnaires & 6 & 9 \\
Total Administered & $\mathbf{7 0}$ & $\mathbf{1 0 0}$ \\
\hline
\end{tabular}

\section{Descriptive Analysis Results}

In this section the study analysed the level of government participation, public relations, and capacity development, national culture and sport commercialization using descriptive statistics. The study used percentages mean and standard deviation to analyse the response based on the statement used to measure the study variables. Descriptive analysis was conducted for all the variables including the dependent variables.

\section{Government Participation}

The objective of the study was to examine the effect of government participation on sport commercialization in Kenya, within the football subsector. The results in Table 4.3 assess the extent of government participations in club football in Kenya.

\section{Table 2 Descriptive Results for Government Participation}

\begin{tabular}{|c|c|c|c|c|c|c|c|}
\hline Statements & SD & $\mathrm{D}$ & $\mathrm{U}$ & A & SA & Mean & Std.Dev \\
\hline $\begin{array}{l}\text { Sufficient funding by } \\
\text { government has led to } \\
\text { setting up of a good } \\
\text { structural and }\end{array}$ & & & & & & & \\
\hline $\begin{array}{l}\text { administrative setup } \\
\text { Successful bidding for } \\
\text { international events due } \\
\text { to enough government } \\
\text { funding has left a legacy } \\
\text { of resulting to sport }\end{array}$ & $3.1 \%$ & $12.5 \%$ & $14.1 \%$ & $32.8 \%$ & $37.5 \%$ & 3.89 & 1.14 \\
\hline $\begin{array}{l}\text { commercialization } \\
\text { Government has } \\
\text { constructed adequate }\end{array}$ & $12.5 \%$ & $7.8 \%$ & $4.7 \%$ & $34.4 \%$ & $40.6 \%$ & 3.83 & 1.38 \\
\hline $\begin{array}{l}\text { stadia } \\
\text { Government has provided } \\
\text { an elaborate sport policy }\end{array}$ & $15.6 \%$ & $7.8 \%$ & $6.2 \%$ & $37.5 \%$ & $32.8 \%$ & 3.64 & 1.42 \\
\hline $\begin{array}{l}\text { framework } \\
\text { Sufficient legislation on } \\
\text { laws relating to proper }\end{array}$ & $7.8 \%$ & $12.5 \%$ & $14.1 \%$ & $29.7 \%$ & $35.9 \%$ & 3.73 & 1.29 \\
\hline governance are an & $4.7 \%$ & $6.2 \%$ & $9.4 \%$ & $32.8 \%$ & $46.9 \%$ & 4.11 & 1.11 \\
\hline
\end{tabular}


incentive to corporate

organizations

Tax rebates and tax

holidays for those

organizations supporting

sport in any way are an

incentive to corporate

organizations

$6.2 \%$

$7.8 \%$

$6.2 \%$

$40.6 \%$

$39.1 \%$

3.98

1.16

Average

3.86

Key: SD-Strongly Disagree, D-Disagree, U-undecided, A-Agree, SA-Strongly Agree

The overall mean in this section was 3.86 which indicated that respondents agreed with government participation in supporting football clubs in Kenya through various ways. The study results revealed that government participation is necessary in improving sports commercialization in Kenya. The study support the findings of Mwisukha \& Mukolwe, (2013) who found that government and governmental organizations constitute the public sector of the sports industry, which is responsible in making sports policies, allocating grants for developing infrastructure, nurturing talents and designing specialized programs for overall development of sports.

\section{Public Relations}

The second objective of the study was to assess the effect of public relations on sport commercialization in Kenya, within the football subsector. The results in Table 3 presents analyze of the level of adoption of the public relations among the football clubs in Kenya.

Table 3: Descriptive Results for Public Relations

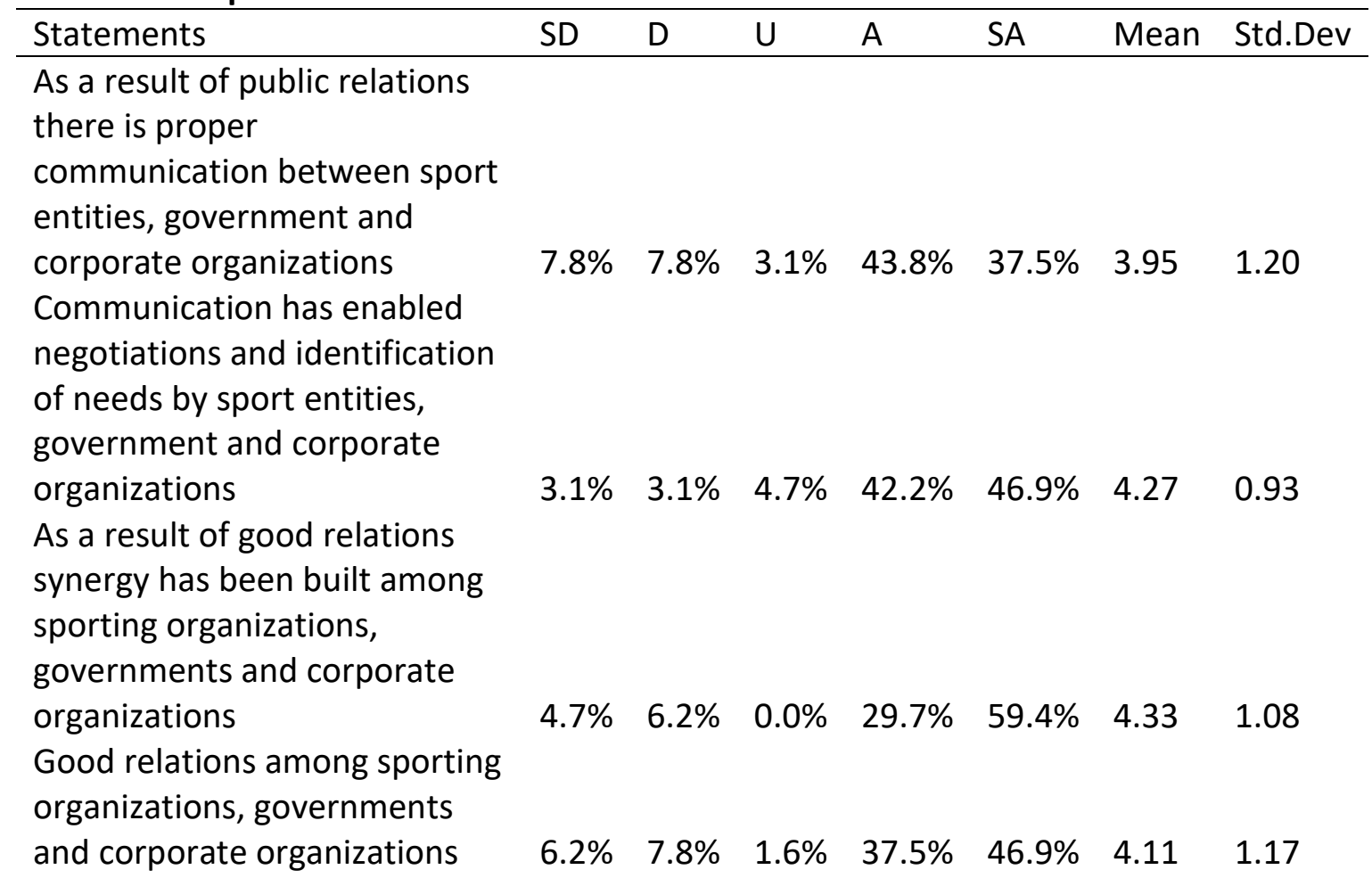


has enable increased

opportunities

Clubs now enjoy positive

image and good reputation

from good Public relations

Government now has good

\begin{tabular}{lllllll}
$1.6 \%$ & $7.8 \%$ & $4.7 \%$ & $46.9 \%$ & $39.1 \%$ & 4.14 & 0.94 \\
$9.4 \%$ & $6.2 \%$ & $3.1 \%$ & $35.9 \%$ & $45.3 \%$ & 4.02 & 1.27 \\
& & & & & 4.14 & \\
\hline
\end{tabular}

The overall mean response of 4.14 and 4.02 further revealed that majority of the respondents strongly agreed and agreed clubs now enjoy positive image and good reputation from good public relations and government had good image due to public relations. Generally, the respondents agreed that public relations had a significant contribution in sport commercialization in Kenya. The findings of this study agreed with Grunig (2013) who argued that communication programs that are managed strategically help organizations to manage relationships with strategic publics that have the power to constrain the ability of the organization to achieve its goals.

\section{Capacity Development}

The third objective of the study was to determine the effect of capacity development on sport commercialization in Kenya, within the football subsector. This section assesses the capacity development and how it affected sport commercialization in Kenya.

\section{Table 4 Descriptive Results for Capacity Development}

\begin{tabular}{|c|c|c|c|c|c|c|c|}
\hline Statements & SD & D & $\mathbf{U}$ & A & SA & Mean & Std.Dev \\
\hline $\begin{array}{l}\text { Fans have increased due more } \\
\text { skillful players as a result of skill } \\
\text { development of coaches } \\
\text { Running of sport organizations is } \\
\text { now more efficient with }\end{array}$ & $6.2 \%$ & $10.9 \%$ & $17.2 \%$ & $32.8 \%$ & $32.8 \%$ & 3.75 & 1.21 \\
\hline $\begin{array}{l}\text { capacity development } \\
\text { Administrative systems are }\end{array}$ & $9.4 \%$ & $7.8 \%$ & $9.4 \%$ & $35.9 \%$ & $37.5 \%$ & 3.84 & 1.28 \\
\hline $\begin{array}{l}\text { running smoothly and efficiently } \\
\text { Match day attendance has }\end{array}$ & $6.2 \%$ & $10.9 \%$ & $6.2 \%$ & $34.4 \%$ & $42.2 \%$ & 3.95 & 1.23 \\
\hline increased to enhanced systems & $6.2 \%$ & $6.2 \%$ & $17.2 \%$ & $35.9 \%$ & $34.4 \%$ & 3.86 & 1.15 \\
\hline $\begin{array}{l}\text { Trust is now evident } \\
\text { Uncontrolled betting, doping }\end{array}$ & $9.4 \%$ & $9.4 \%$ & $4.7 \%$ & $37.5 \%$ & $39.1 \%$ & 3.88 & 1.29 \\
\hline and match fixing are controlled & $6.2 \%$ & $15.6 \%$ & $10.9 \%$ & $37.5 \%$ & $29.7 \%$ & 3.69 & 1.23 \\
\hline Average & & & & & & 3.83 & \\
\hline
\end{tabular}

Key: SD-Strongly Disagree, D-Disagree, U-undecided, A-Agree, SA-Strongly Agree

The findings in this section demonstrated that football clubs in Kenya have developed their capacity in various ways which has affected their relationship with various stakeholders 
leading to increased demand in commercialization. These finding are in agreement with Mwisukha \& Mukolwe (2013) who noted that country needs a sound and well established program for training of necessary manpower in sports to alleviate manpower shortage currently being experienced.

\section{National Culture}

The fourth objective of the study was to examine the effect of national culture on sport commercialization in Kenya, within the football subsector.

Table 5 Descriptive Results for National Culture

\begin{tabular}{|c|c|c|c|c|c|c|c|}
\hline Statements & SD & D & $\mathbf{U}$ & A & SA & Mean & Std.Dev \\
\hline $\begin{array}{l}\text { Love of the game has triggered } \\
\text { ticket sales have increase } \\
\text { If I don't book my ticket early I }\end{array}$ & $7.8 \%$ & $6.2 \%$ & $1.6 \%$ & $32.8 \%$ & $51.6 \%$ & 4.14 & 1.22 \\
\hline might not get space & $3.1 \%$ & $6.2 \%$ & $4.7 \%$ & $54.7 \%$ & $31.2 \%$ & 4.05 & 0.95 \\
\hline $\begin{array}{l}\text { More teams are being formed } \\
\text { because of more than enough } \\
\text { players }\end{array}$ & $3.1 \%$ & $6.2 \%$ & $4.7 \%$ & $43.8 \%$ & $42.2 \%$ & 4.16 & 1.00 \\
\hline $\begin{array}{l}\text { Teams are competing more } \\
\text { competitively due ro } \\
\text { completion for space among } \\
\text { players }\end{array}$ & $6.2 \%$ & $3.1 \%$ & $4.7 \%$ & $45.3 \%$ & $40.6 \%$ & 4.11 & 1.07 \\
\hline $\begin{array}{l}\text { There is an increased number of } \\
\text { community clubs in the league }\end{array}$ & $3.1 \%$ & $4.7 \%$ & $9.4 \%$ & $40.6 \%$ & $42.2 \%$ & 4.14 & 0.99 \\
\hline $\begin{array}{l}\text { Community clubs have more } \\
\text { fans than other clubs } \\
\text { Average }\end{array}$ & $6.2 \%$ & $4.7 \%$ & $6.2 \%$ & $46.9 \%$ & $35.9 \%$ & $\begin{array}{l}4.02 \\
4.10\end{array}$ & 1.09 \\
\hline
\end{tabular}

Key: SD-Strongly Disagree, D-Disagree, U-undecided, A-Agree, SA-Strongly Agree

This finding demonstrated that culture played a significant role in the growth of the football clubs in Kenya leading to commercialization of the sporting activities in football subsector in Kenya. Accordingly, Oliver (2014) argued that sport is at the forefront of cultural and civil change in part because sport is an affirmation of societal values. With the ability to bring communities together, sport is revered and teams have very dedicated fan bases.

\section{Sports Commercialization}


This section presents the descriptive statistics on sport commercialization in football subsector in Kenya.

Table 7 Descriptive Results for Sports Commercialization

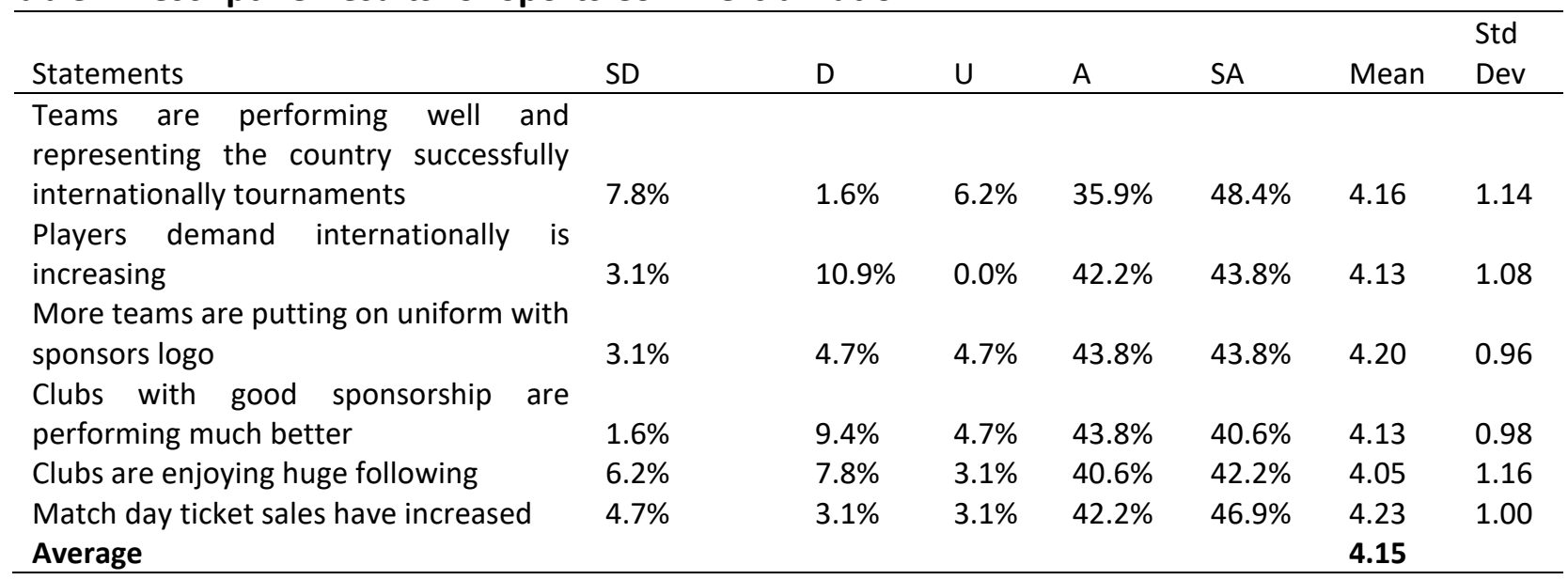

Key: SD-Strongly Disagree, D-Disagree, U-undecided, A-Agree, SA-Strongly Agree

These findings points to increasing popularity of the sport commercialization in Kenya. The study findings concur with Ki-moon (2011) who argues that sport has become a world language, a common denominator which breaks all the barriers, a worldwide industry and a powerful tool for progress and development. According to Agutu (2018) sponsorship deals as a result of growth of sports commercialization also open up doors for more international exchange programmers for both players and coaches.

\section{Inferential Statistics}

This section presents the inferential statistics that were conducted to test the relationship between independent variables and dependent variables. The inferential statistics that the study used include correlation and regression analysis. Correlation analysis was used to test the association between independent variables and dependent variable while regression was used to test the significance of the relationship between independent variables and dependent variable.

\section{Correlation Analysis}

Table 8 shows the results of correlation analysis conducted to test the association between independent variables and dependent.

Table 4.8 Correlation Matrix

\begin{tabular}{|c|c|c|c|c|c|c|}
\hline & & $\begin{array}{l}\text { Government } \\
\text { Participation }\end{array}$ & $\begin{array}{l}\text { Public } \\
\text { Relations }\end{array}$ & $\begin{array}{l}\text { Capacity } \\
\text { Developmen } \\
\mathrm{t}\end{array}$ & $\begin{array}{l}\text { National } \\
\text { Culture }\end{array}$ & $\begin{array}{l}\text { Sports } \\
\text { Commerc } \\
\text { ialization }\end{array}$ \\
\hline Government & Pearson & & & & & \\
\hline Participation & Correlation & 1 & & & & \\
\hline Public & Pearson & & & & & \\
\hline Relations & Correlation & $.389 * *$ & 1 & & & \\
\hline
\end{tabular}




\begin{tabular}{lllllll}
$\begin{array}{l}\text { Capacity } \\
\text { Development }\end{array}$ & $\begin{array}{l}\text { Pearson } \\
\text { Correlation } \\
\text { Pearson }\end{array}$ & $.334^{* *}$ & $.446^{* *}$ & 1 & \\
$\begin{array}{l}\text { Culture } \\
\text { Sports }\end{array}$ & $\begin{array}{l}\text { Correlation } \\
\text { Commercializ }\end{array}$ & $.363^{* *}$ & $.575^{* *}$ & $.614^{* *}$ & 1 \\
Pearson & & & & & \\
ation & $\begin{array}{l}\text { Correlation } \\
\text { Sig. }\end{array} \quad(2-$ & $.329^{* *}$ & $.860^{* *}$ & $.880^{* *}$ & $.770^{* *}$ & 1 \\
& $\begin{array}{l}\text { tailed) } \\
\mathbf{N}\end{array}$ & 0.008 & 0.000 & 0.000 & 0.000 & \\
& 64 & 64 & 64 & 64 & 64 \\
\hline
\end{tabular}

** Correlation is significant at the 0.05 level (2-tailed).

The results shows that government participation and sport commercialization had correlation of $r=0.329(p=0.000)$. This results show that government participation had a positive association with sports commercialization in football subsector in Kenya. The results further show that public relations and sports commercialization had a correlation of $r=0.860$, $(p=0.000)$ which indicated that public relations had a strong and positive association with sport commercialization in Kenya. The results also show that capacity development and sports commercialization had a correlation of $r=0.880,(p=0.000)$ which indicated that capacity development had a strong and positive association with sport commercialization in Kenya. According to the study results national culture and sports commercialization had a correlation of $r=0.770,(p=0.000)$ which indicated that national culture had a strong and positive association with sport commercialization in Kenya.

The results show that government participation, public relations, capacity development and national cultture had a positive and strong association with sports commercialization in football subsector in Kenya. The study support the findings of Mwisukha \& Mukolwe, (2013) who found that government and governmental organizations constitute the public sector of the sports industry, which is responsible in making sports policies, allocating grants for developing infrastructure, nurturing talents and designing specialized programs for overall development of sports. The findings of this study agreed with Grunig (2013) who argued that communication programs that are managed strategically help organizations to manage relationships with strategic publics that have the power to constrain the ability of the organization to achieve its goals.

\section{Multivariate Regression Analysis Results}

The study employed multivariate regression analysis to test the relationship between independent variables and dependent variables.

Table 9 Model Summary

\begin{tabular}{lccccc}
\hline Model & $\mathrm{R}$ & $\mathrm{R}$ Square & $\begin{array}{l}\text { Adjusted } \\
\text { Square }\end{array}$ & $\begin{array}{l}\mathrm{R} \\
\text { Std. Error of } \\
\text { the Estimate }\end{array}$ \\
\hline 1 & $.777^{\mathrm{a}}$ & .604 & .578 & .57280 \\
\hline a Predictors: & (Constant), National Culture, & Government \\
Development, Public Relations
\end{tabular}


The results of model summary presented in Table 9 shows coefficient of determination of $\mathrm{R}^{2}$ $=0.604$ which implied that government participation, public relations, capacity development and national culture accounted for $60.4 \%$ of the variation in sport commercialization. The findings implied that government participation, public relations, capacity development and national culture were significant strategic drivers of sports commercialization in football subsector in Kenya.

Table 10 Analysis of Variance (ANOVA)

\begin{tabular}{lllllll}
\hline \multirow{2}{*}{ Model } & & \multicolumn{3}{c}{ Sum of } & \multicolumn{2}{l}{ Mean } \\
Squares & df & Square & F & Sig. \\
\hline 1 & Regression & 29.586 & 4 & 7.396 & 22.543 & $.000^{\mathrm{b}}$ \\
& Residual & 19.358 & 59 & 0.328 & & \\
& Total & 48.944 & 63 & & & \\
\hline
\end{tabular}

a Dependent Variable: Sports Commercialization

b Predictors: (Constant), Culture, Government Participation, Capacity Development, Public Relations

The study used ANOVA to determine whether the regression model used to link strategic drivers (government participation, public relations, capacity development and national culture) had a significant impact on sports commercialization in football subsector in Kenya. The results in Table 10 shows $f$-statistics $=22.543(p=0.000)$ which was less than 0.05 meaning that regression model was statistically significant and government participation, public relations, capacity development and national culture could significantly predict sports commercialization in football subsector in Kenya.

Table 11 Regression Coefficients

\begin{tabular}{llllll}
\hline & $\beta$ & Std. Error & Beta & $\mathrm{t}$ & Sig. \\
\hline (Constant) & 0.314 & 0.122 & & 2.58 & 0.012 \\
Government Participation & 0.227 & 0.084 & 0.25 & 2.713 & 0.009 \\
Public Relations & 0.274 & 0.113 & 0.276 & 2.435 & 0.018 \\
Capacity Development & 0.612 & 0.119 & 0.506 & 5.131 & 0.000 \\
National Culture & 0.229 & 0.089 & 0.214 & 2.556 & 0.013 \\
\hline
\end{tabular}

a Dependent Variable: Sports Commercialization

Table 11 presents the results of regression coefficients showing the magnitude, significance and direction of the relationship between independent variables and dependent variable. The results show government participation had $\beta=0.227, p=0.009<0.05$. The results show that government participation had significant effect on sports commercialization in football subsector. The findings implied that government participation provided an environment for football clubs to grow and had insignificant effect on commercialization. The results show public relations had $\beta=0.274, p=0.018<0.05$. The results show that public relations had a positive and significant effect on sports commercialization in football subsector. The results indicate that unit increase in public relations would results to 0.274 units increase in sports commercialization. The results of regression coefficients further show capacity development 
had $\beta=0.612, p=0.000<0.05$. These results confirmed that capacity development had a positive and significant effect on sports commercialization in football subsector. The results indicate that unit increase in capacity development would results to 0.612 units increase in sports commercialization. Finally, the results of regression coefficients further show national culture had $\beta=0.229, p=0.013<0.05$. These results confirmed that national culture had a positive and significant effect on sports commercialization in football subsector. The results indicate that unit increase in culture adoption in sporting activities would results to 0.229 units increase in sports commercialization.

The finding supports those of Mwisukha \& Mukolwe (2013) who argues that government participation is through the making of sports policies, allocating grants for developing infrastructure, nurturing talents and designing specialized programs for overall development of sports. The study finding also concur with Serbanica \& Constantinescu (2016) who argue that amount of money invested in and made by professional sport today and the complexity of those revenue sources have forged an important symbiotic relationship between the media, global PR activity, and professional sport. The finding further concurs with Ratten (2014) who found that Sports entrepreneurs and mangers engage in innovative activity that enhances their ability to use creatively and dynamically their resource base. Thus, they are people who enact ideas, information and practices for the purpose of engaging in a business venture. Mwisukha \& Mukolwe, (2013) also argue that there is a need for sound and well established programs for training of necessary manpower in sports to alleviate manpower shortage currently being experienced.

\section{Conclusions}

The study's major findings were that government participation had a positive association with sports commercialization in football subsector in Kenya. The findings implied increasing government participation would lead to increase in sport commercialization. The findings further implied that government participation provided an environment for football clubs to grow and had significant effect to sports commercialization in football subsector in Kenya. On the second predictor, effect of public relations on sport commercialization in Kenya, within the football subsector, results show that public relations and sports commercialization had a strong and positive association with sport commercialization in Kenya and that increasing public relations would lead to increase in sports commercialization in football subsector in Kenya.

The third predictor of the study was to determine the effect of capacity development on sport commercialization in Kenya, within the football subsector. The findings revealed that increasing capacity development would lead to increase in sports commercialization in football subsector in Kenya. Finally on the last predictor which was national culture on sport commercialization in Kenya, within the football subsector. The descriptive findings demonstrated that culture played a significant role in the growth of the football clubs in Kenya leading to commercialization of the sporting activities in football subsector in Kenya. The results of regression coefficients confirmed that culture had a positive and significant effect on sports commercialization in football subsector. The study concluded that government participation was critical in ensuring the football clubs in Kenya have the necessary policy and 
infrastructure necessary for sporting clubs to grow and that government plays a very significant role in ensuring sport commercialization.

The study further concluded that sporting organizations in Kenya should adopt public relations as this shall enable them commercialize their sporting activities. Public relations shall enable negotiations and identification of needs by sport entities, government and corporate organizations and as a result of good relations synergy shall be built among sporting organizations, governments and corporate organizations. The study concluded that continuous adoption of public relations shall increase sports commercialization in football subsector in Kenya.

In regards to capacity development, the study concluded that football clubs in Kenya are in the process of building their capacity in terms of enhanced operational systems, skill capacity and administrative systems. Capacity development among the sporting clubs is at the centre of sports commercialization which explains why majority of the clubs are setting up systems and structures to build efficient and enduring clubs. The study finally concluded that national culture is essential in football clubs development and that majority of the clubs with national culture identity have managed to commercialize their sporting activities. National culture is a significant player in sports commercialization in the Kenyan football subsector.

\section{Recommendations}

This study recommends that clubs continue closely working with the government in order to collectively plan way forward on additional support through bodies like the Football Kenya Federation and Kenya Premier League. Among the major contributions by government would be the provision of sufficient funding that would aid in setting up strong structural and administrative setup that would include stadiums and modern training facilities across the country. Other contributions by government should include elaborate policy framework which should include sufficient legislation on laws relating to proper governance as well as those laws that would work as an incentive to corporate organizations; incentives like tax rebates and tax holiday for those organizations supporting sport.

The study further recommends that football clubs should have operational and functional public relations departments with experts to enabled negotiations and identification of needs that would enable closer and mutual beneficial association with sporting entities, government and corporate organizations. Football clubs should use good relations synergy to build high performing sporting organizations that would leverage on these good relations to attract corporate sponsorship and positive partnerships with the government. Good public relations shall enable negotiations and identification of needs between sport entities, government and corporate organizations leading to increased opportunity for all stake holders.

The study recommends that management of football organizations should develop capacity development structures and systems necessary for the growth and development of talented players, better equipped coaches as well as enhanced systems and processes. This shall lead to the formation of more competitive teams as well as enhanced administrative systems and processes within the clubs setup. As a result there would be growth in game attendance making, clubs, target for marketing by corporate organizations and sponsors. 
Finally the study recommends that all stakeholders including football associations and football clubs should engage in activities that will ensure that football culture is developed in the country. This includes coming up with modalities that would reduce incidents of violence in football stadiums on match days which scare away fans. They should also engage in corporate social responsibility activities in order to attract following as well as increase social impacts among others. The result would be more affiliation to clubs by fans. Packed stadiums, apart from attracting sponsors also increase revenue to the clubs.

\section{References}

Agutu, N. (2018). SportPesa signs new Shs 682.4 million deals with Kenya football clubs. The Star, Retrieved from https://www.the-star.co.ke

Alapartanen, N., \& Kelly, D. (2016). Understanding the Implications of the Sporting Industry in the United Kingdom and the United States. Retrieved from https://www.theseus.fi/bitstream/handle/10024/119464/Alapartanen_Niko_and_K elly_Daniel.pdf?sequence $=1 \&$ isAllowed $=y$

Alegi, P. \& Bolsmann, C. (2013). South Africa and the global game: Football, apartheid and beyond. London, UK: Routledg Publishers

Baker, J. (2014). Marketing strategy and management. London, UK: Palgrave Publishers

Barney, J. (1991). Firm resources and sustained competitive advantage. Journal of Management, 17, 99-120. http://dx.doi.org/10.1177/014920639101700108

Bullock, A. \& Trombley, S. (1999). The New Fontana Dictionary of Modern Thought. London, UK: Harper Collins.

Deloitte. (2018). Annual review of football finance. Retrieved from https://www2.deloitte.com/content/dam/Deloitte/uk/Documents/sports-businessgroup/deloitte-uk-sbg-annual-review-of-football-finance-2018.

Doherty, A., Misener, K., \& Cuskelly, G. (2014). Toward a multidimensional framework of capacity in community sport clubs. Nonprofit and Voluntary Sector Quarterly. Retrievd from https://doi.org/10.1177/0899764013509892

Edwards, M. B. (2015). The role of sport in community capacity building: An examination of sport for development research and practice. Sport management review, 18(1), 6-19. doi.org/10.1016/j.smr.2013.08.008

Göksel, A. G., \& Serarslan, M. Z. (2015). Public relations in sports clubs: New media as a strategic corporate communication instrument. International Journal of Physical Education, Sports and Health, 2(2), 275-283. Retrieved from https://www.academia.edu/34799586/Public_relations_in_sports_clubs_New_medi a_as_a_strategic_corporate_communication_instrument

Grunig, J. E. (2013). Excellence in public relations and communication management. doi: https://doi.org/10.4324/9780203812303

Hopwood, M., Skinner, J., \& Kitchin, P. (2012). Sport public relations and communication. London, UK: Routledge Publishers

Hopwood, M. K. (2015). Public relations practice in English county cricket. Corporate Communications: An International Journal, 10(3), 201-212. Retrieved from https://www.emerald.com/insight/content/doi/10.1108/13563280510614465/full/h tml

Houlihan, B. (2009). Mechanisms of international influence on domestic elite sport policy. International journal of sport policy and politics, 1(1), 51-69. 
Ki-moon, B. (2011). Sport is a vital tool for peace building and development. Retrieved from https://news.un.org/en/story/2011/05/374702

Kothari, C. (2004). Research methods. New Dehli, India: John Wiley \& Sons Publishers

Lustig, M. (2013). Intercultural competence: Interpersonal communication across cultures. New York, NY: Pearson Publishers

Mwisukha, A. \& Mukolwe, N. (2013).Strategy for promoting sport in Kenya. Retrieved from http://hdl.handle.net/123456789/6790

Oliver, P. (2014). The power of sport: Building social bridges and breaking down cultures. Retrieved from https://handle//20.500.11937/535/229641

Potts, J. \& Thomas, S. (2018). Toward a new evolutionary economics of sports. Sport, business and management: An International Journal, 8(1), 82-96. Retrieved from https://www.emeraldinsight.com/doi/abs/10.1108/SBM-04-2017-0023

Ratten, V. (2014). Sport innovation: The role of social entrepreneurship and creativity in fostering sport related business activities. Retrieved from http://www. Mams.remit.edu.au/y9yd9oljmiuc.pdf

Serbanica, D. \& Constantinescu, M. (2016). Using public relations in sports. Romanian Journal of Marketing. Retrieved from https://www.researchgate.net/publication/ 305044397

Slack, T. (2014). The social and commercial impact of sport, the role of sport management. European Sport Management Quarterly, 14(5), 454-463.

Sport \& Recreation South Africa. (2012). 2010 FIFA World Cup Country Report. Retrievedfromhttp://www.srsa.gov.za/MediaLib/Home/DocumentLibrary/SRSAC ountryReport2013-withcover.pdf

Statista. (2015). North American sports sponsorship spending from 2009 to 2015.Retrieved from

http://www.statista.com/statistics/284687/sports-sponsorship-spending-in-northamerica-2014/

Westerbeek, H. (2013). Global sport business: Community impacts of commercial sport. London, UK: Routledge Publishers

Yadav, D. (2016). Commercialization of sport and competition law. Retrieved from https://www.researchgate.net/publication/311912413 